УДК 613.6.015/02:15月.91

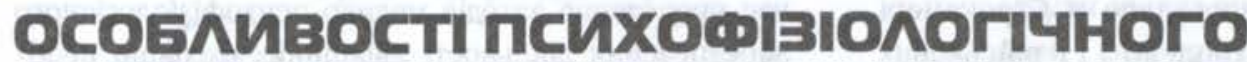 СТАНУ вІЙСЬКОвИХ АЬОтЧИКІв РІВНОГО BIKY I CTAHY $3 \triangle O P O B '$
}

\section{Кравчук В.в.}

\section{Українська військово-медична акацемія, м. Київ}

Представлено нові підходи до вирішення актуальної проблеми фізіології та гігієни праці військових фахівців оцінки психофізіологічного стану військових льотчиків різного віку і стану здоров'я. Встановлено особливості мобілізації резервів адаптації їнього організму, а також вікової трансформації взаємозв'язків психофізіологічних функцій. Розроблено рекомендації щодо вдосконалення тактики застосування профілактичних і реабілітаційних заходів серед військових льотчиків з урахуванням їх віку і стану здоров'я.

Ключові слова: військові льотчики, професійна діяльність, психофізіологічні функції, стан здоров'я, резерви адаптації, вік

\section{Вступ}

На сучасному етапі розвитку авіації проблема збереження високого рівня здоров'я і працездатності авіаційних фахівців протягом усього періоду проходження військової служби стала пріоритетною у забезпеченні високого рівня їх боєготовності.

Праця військового льотчика пов'язана 3 постійним впливом комплексу фізіологічно незвичних і шкідливих факторів професійної діяльності [4 та iн.]. Як показує досвід вітчизняних і зарубіжних авторів [14, 16 та ін.], такі умови діяльності висувають серйозні вимоги до функціональних можливостей авіаційних фахівців. Унаслідок дії комплексу професійно зумовлених факторів адаптаційні можливості військових льотчиків досить швидко знижуються, що суттево впливає на ефективність і надійність виконання ними службових обов'язків і значно погіршує стан іхнього здоров'я [4 та ін.]. Крім того, недостатнє професійне навантаження [12]призводить до значного і постійного підвищення нервово-емоційного напруження [2, 15 та ін.], а також суттевого напруження адаптаційних регуляторних механізмів [13 та ін.]. Значною мірою розвитку та виникненню такої ситуації сприяє існуюча на сьогодні складна соціально-економічна, демографічна та екологічна ситуація в Україні [9].

Вивченню дії чинників трудового середовища на працездатність і професійне здоров'я фахівців різного віку прнділяеться достатньо багато уваги $[5$, 11 та ін.]. Проте дослідження комплексного впливу факторів віку і стану здоров'я на психофізіологічний стан осіб льотного складу на сьогоднішній день лишаються поза увагою науковців, хоча вони $\epsilon$ актуальними для розвитку теоретичних і практич- них аспектів фізіології і гігіени праці авіаційних фахівців.

Мета досліджень - розробити, на основі виявлення особливостей впливу віку і стану здоров'я на психофізіологічний стан військових льотчиків, підходи до його оцінки для удосконалення тактики застосування профілактичних і реабілітаційних заходів.

\section{Матеріали та методи досліджень}

Об'єктом дослідження були особи льотного складу (ЛС) Повітряних сил (ПС) Збройних Сил (3С) України в період проходження стаціонарної лікарсько-льотної комісії на базі Військово-медичного центру (ВМЦ) ПС ЗС України. Обстежуваних було розподілено за віком та станом здоров'я на 4 групи: А - особи ЛС до 30 років з I групою здоров'я; Б - особи ЛС віком $31-40$ років з I групою здоров'я; В - особи ЛС до 30 років з II групою здоров'я; Г - особи ЛС віком $31-40$ років з II групою здоров'я. При цьому слід зауважити, що до I групи здоров'я належать здорові особи ЛС, які не мають жодних захворювань або мають деякі відхилення в стані здоров'я без тенденції до їх прогресування, що не впливають на працездатність. До II групи здоров'я належать практично здорові особи ЛС, які мають хронічні захворювання без порушення або 3 незначним порушенням функцій органів і систем, що не знижують працездатності вказаних військовослужбовців.

Функціональний стан досліджуваних перебував на сталому рівні завдяки однаковим умовам і режимам перебування у медичному закладі.

Дослідження резервів адаптації здійснювали за допомогою адекватного для ціеї професії наванта- 
ження - дослідження переносимості помірних ступенів гіпоксії, яке було проведено у барокамері УСБК-80. Обстеженням охоплено 111 військових льотчиків. Як індикатор змін функціонального стану було використано серцевий ритм (СР) [1]. Вибір цього показника визначався його якістю: спрямований вплив на параметри $\mathrm{CP} є$ можливим тільки за наявності специфічних навичок, що були відсутні у досліджуваного контингенту. СР реєструвався у два етапи: перша фаза - до навантаження (у період відносного спокою) і друга - через 10 хвилин після навантаження (у період відновлення) у позі лежачи, в другому стандартному відведенні. Реєструвалося 100 кардіоінтервалів.

Дослідження психофізіологічного стану військових льотчиків здійснювали за допомогою спеціально створеного комплексу комп'ютерних тестів (Сертифікат №UAl.092.94579-04), до якого входили модифіковані методики, що застосовуються для психофізіологічного відбору працівників, чия робота пов'язана з виконанням робіт підвищеної небезпеки. Загальна кількість обстежених 79 осіб.

Статистичний аналіз отриманих показників здійснювали за допомогою методів варіаційної статистики, дисперсійного, факторного та кореляційного аналізів.

\section{Результати досліджень}

Перш ніж викласти і обговорити отримані результати досліджень, необхідно зробити деякі зауваження.

По-перше, усі обстежені є діючими льотчиками і здатні якісно виконувати свої професійні обов'язки, a іх функціональний стан зберігається на належному рівні.

По-друге, виділені вікові групи є стандартними i відображають ті закономірні вікові зміни в організмі льотчиків, що відбуваються природним чином, але їх інтенсивність, імовірно, пов'язана не тільки 3 віком, але і з певними відхиленнями стану здоров'я.

По-трете, вікові зміни резервів адаптації льотчиків перебувають під дією ще одного фактора, а саме фактора стажової тренованості організму до впливу специфічних льотних навантажень.

Враховуючи викладене вище, стає можливим сформулювати робочу гіпотезу наших досліджень: адаптаційні резерви організму льотчиків, разом 3 наведеними раніше факторами, формуються за рахунок факторів віку, стану здоров'я та рівня стажової тренованості організму. При цьому для адекватної оцінки цих резервів і практичного використання під час проведення заходів медико-психофізіологічного забезпечення діяльності авіаційних фахівців необхідно враховувати дію окреслених факторів.

Для підтвердження сформульованої гіпотези і адекватної оцінки резервів адаптації організму військових льотчиків було досліджено структуру кореляційних взаємозв'язків між показниками СР (рис. 1) під час впливу гіпоксичного навантаження.

Для описання отриманих даних доцільно використовувати положення Н.П.Бехтеревой [3] про «жорсткі» $\mathrm{i}$ «пластичні» зв'язки. В контексті наведеного обговорення «жорсткими» можна вважати зв'язки, що не змінюються в результаті функціонального навантаження, а «пластичними» - такі, що з'являються або зникають під дією цього навантаження.

Звертаючись 3 цієї позиції до аналізу результатів оцінки резервів адаптації групи А, потрібно підкреслити, що в цій групі параметри СР досить гарно корелюють між собою (виділяються $27 \%$ зв'язків від максимальної кількості), причому $75 \%$ н них $€$ «жорсткими», оскільки після навантаження зберігаються. Крім того, відсутність вірогідності змін структури взаємозв'язків в обох фазах дослідження свідчить про стаціонарність механізмів регуляції процесів адаптації, викликану значним рівнем функціональних резервів.

У групі Б виділяеться $20 \%$ кореляційних зв'язків від максимальної кількості. Після навантаження тут спостерігається значне ( $\mathrm{P}<0,001)$ зменшення іх кількості. Привертає увагу відсутність «жорстких» зв'язків.

Характеризуючи зміни регуляції СР серед здорових льотчиків (групи А і Б), можна відмітити, що 3 віком вони призводять до значної перебудови структури взаємозв'язків у період відносного спокою, проте іх кількість вірогідно не змінюеться. Після гіпоксичного навантаження спостерігається значне $(\mathrm{P}<0,001)$ зменшення таких зв'язків - від $20 \%$ до $7 \%$. Імовірно, це відбувається за рахунок того, що молоді нестажовані льотчики на будь-які зміни умов діяльності реагують мобілізацією значних резервів адаптації, а у більш старших, які частіше потрапляли до різних складних професійних ситуацій, тренування цих функцій веде до іншого механізму мобілізації резервів, залежного від конкретної ситуації. Це дозволяє організовувати функціонування організму таким чином, що формуеться «оптимальна» відповідь організму для пристосування до конкретних умов діяльності. 
Гр. А - здорові до $30 \mathrm{p}$.
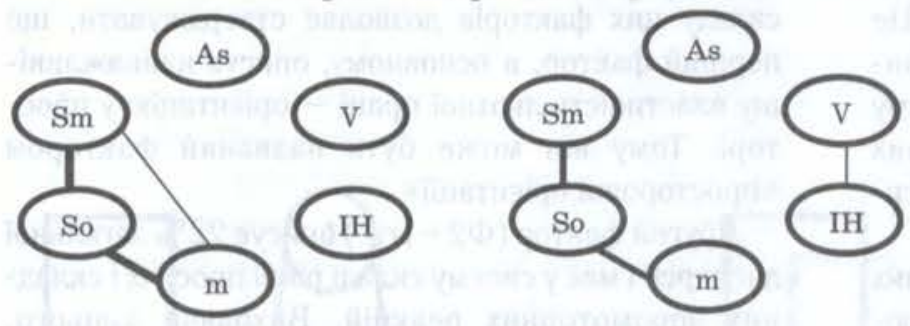

Гр. Б здорові $31-40$ p.

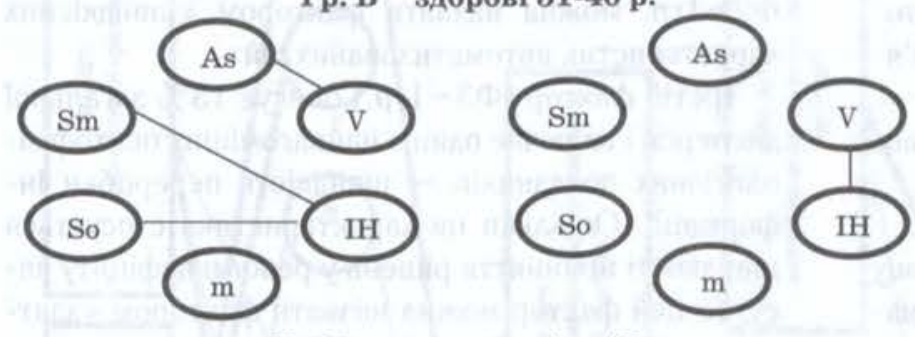

Гр. В - пр. здорові до 30 р.
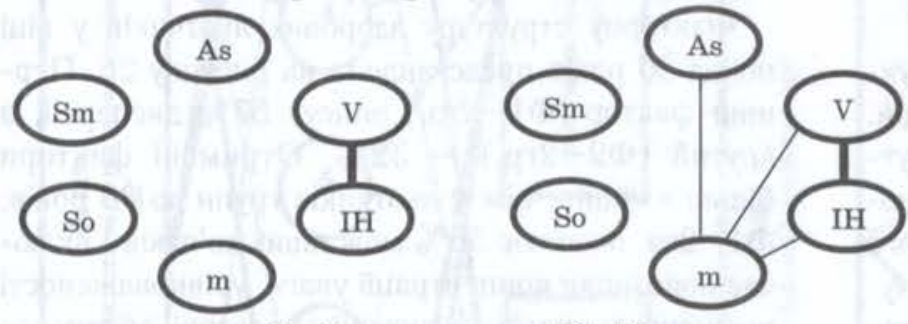

Гр. $\mathrm{\Gamma}$ пр. здорові 31-40 p.

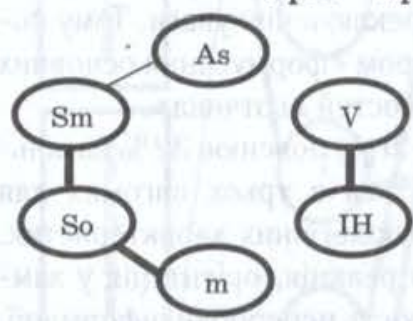

Стан відносного спокою

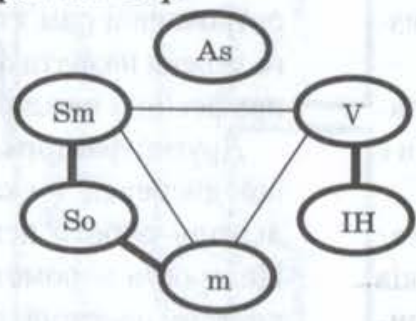

Через 10 хв після навантаження

Рис. 1. Структура розподілу кореляційних зв'язків між показниками СР серед різних груп льотчиків у різні періоди дослідження. Примітки: жирні лініі - кжорсткі» кореляційні зв'язки; тонкі лініі «пластичні» кореляційні зв'язки.

As - асиметрія; V-індекс варіації; IH - індекс напруги (Р.М.Баєвського) : $m$ - кількість зрушень до периого негативного коефіцієнта кореляції; Sо - значення спектра на нульовій частоті; Sm - потужність повільних хвиль.

Дещо інша картина спостерігаеться у групі практично здорових осіб ЛС до 30 років (група В). Тут у період відносного спокою виділяеться $7 \%$ «жорстких» зв'язків. Разом з тим, гіпоксичне навантаження призводить до появи ще чотирьох ( $26 \%$ від максимальної кількості) «пластичних» зв'язків, що разом 3 «жорстким» зв'язком у сумі складае $33 \%$, тобто ї кількість вірогідно ( $\mathrm{P}<0,001)$ зростае після навантаження. При порівнянні груп А і В (групи одного віку, що відрізняються за станом здоров'я) встановлено вірогідне $(\mathrm{P}<0,001)$ зменшення кількості взаємозв'язків до навантаження і збільшення $(\mathrm{P}<0,05)$ - після навантаження за рахунок часткової перебудови їх структури.

До навантаження у групі Г встановлено $20 \%$ «жорстких» зв'язків та $7 \%$ «пластичних». Після навантаження відмічаеться зростання кількості кореляційних зв'язків за рахунок $20 \%$ «пластичних». Таким чином, кількість усіх зв'язків після навантаження вірогідно $(\mathrm{P}<0,05)$ зростає і сумарно становить $40 \%$ від максимально можливих. Порівняння груп Б і Г (групи одного віку, що відрізняються за станом здоров'я) дозволило встановити значну перебудову структури взаємозв'язків при незначній зміні їх кількості до навантаження, а також вірогідне $(\mathrm{P}<0,001)$ збільшення ціеї кількості після навантаження.

Така ситуація свідчить про те, що серед практично здорових осіб ЛС на фоні зниження резервів адаптації організму, зумовленого наявністю захворювань, спостерігаеться значне напруження резервів адаптації у відповідь на адекватне для даної професійної групи гіпоксичне навантаження. Причому, з віком відмічається зростання цього напруження. Окремо слід звернути увагу на відсутність позитивного впливу стажової тренованості на формування механізмів адаптації серед осіб ЛС з II групою здоров'я.

У сучасних літературних джерелах $[4,9$ та інші] питанням комплексної оцінки резервів адаптації організму працівників різних спеціальностей, які відрізняються важкістю і напруженістю праці, приділяеться досить багато уваги. Основним результатом цих досліджень е встановлення закономірностей змін цих резервів у різних умовах професійної діяльності та виявлення зв'язку зі станом регуляторних систем організму працюючих залежно від віку. Разом з тим, привертає увагу наявність певних протиріч поданих даних та відсутність аналізу взаемозв'язків між окремими параметрами регуляторних систем організму. Саме тому у приведених дослідженнях на основі аналізу взаємозв'язків між параметрами СР було оцінено меха- 
нізми мобілізації резервів адаптації серед осіб різних не тільки за віком, а й за станом здоров'я. Це дає змогу більш диференційовано підходити до вирішення питань професійної придатності, у даному випадку льотчиків, до виконання професійних обов'язків під час проведення заходів медико-психофізіологічного забезпечення іх діяльності.

Підходи до аналізу структури психофізіологічних функцій полягають у тому, що на функції працюючої людини під час іх становлення в процесі багаторічної діяльності діє декілька факторів, які пов'язані з:

- закономірними віковими змінами психофізіологічного стану;

- тренуванням професійно важливих якостей;

- негативним впливом функціонального стану фахівців при погіршенні їхнього здоров'я, навіть у стані ремісії, що неоднаково діє на працездатність людини.

Останне позначається не тільки на самій структурі взаємозв'язків психофізіологічних функцій, але й на іх рівні та спрямованості. У випадку відсутності кореляційного зв'язку, очевидно, можна говорити про радикальну перебудову кореляційного каркасу психофізіологічних функцій, що забезпечують професійну діяльність, а у випадку появи негативних зв'язків - про закономірну інверсію зв'язків цього каркасу.

Структуру кореляційного каркасу можна виявити кількома шляхами. Одним з ефективних шляхів $е$ проведення факторного аналізу.

Факторну структуру психофізіологічного забезпечення професійної діяльності здорових льотчиків різного віку та стану здоров'я представлено на рисунку 2.

Психофізіологічні характеристики здорових льотчиків віком до 30 років описуються трьома незалежними факторами, що у своїй сукупності пояснюють $67 \%$ дисперсії вихідних даних. Цікаво, що факторна структура «старшої» групи (понад 30 років) більш компактна і складається 3 двох факторів, що пояснюють $89 \%$ дисперсії вихідних даних. Це свідчить про більшу структурованість психофізіологічних характеристик льотчиків «старшої» групи, яку можна пояснити кращою пристосованістю їхніх організмів до виконання льотної роботи (внаслідок тренування професійно важливих якостей).

Як уже зазначалося, факторну структуру здорових льотчиків віком до 30 років представлено трьома факторами (рис. 2а). Перший з них (Ф1-1гр.) має описову потужність $32 \%$, другий (Ф2-1гр.) -
$22 \%$, третій (Ф3-1гр.) - 13\%. Змістовний аналіз складу цих факторів дозволяе стверджувати, що перший фактор, в основному, описуе найважливішу властивість льотної праці - орієнтацію у просторі. Тому він може бути названий фактором «просторової орієнтації».

Другий фактор (Ф2-1гр.) описує $22 \%$ загальної дисперсії і має у своему складі рівні простих і складних зоромоторних реакцій. Виходячи з цього, Ф2-1гр. можна назвати фактором «швидкісних характеристик автоматизованих дій».

Третій фактор (Ф3-1гp.) описує 13\% загальної дисперсії і включае один з найвагоміших психофізіологічних показників - швидкість переробки інформації. Оскільки ця характеристика стосуеться швидкості прийняття рішень у режимі дефіциту часу, то цей фактор можна назвати фактором «здатності працювати за умов дефіциту часу».

Факторну структуру здорових льотчиків у віці понад 30 років представлено на рисунку 26 . Перший фактор (Ф1-2гр.) описуе $57 \%$ дисперсії, а другий (Ф2-2гр.) - 32\%. Отримані фактори більш «міцні», ніж у льотчиків групи до 30 років. Ф1-2гр. охоплюе $56 \%$ можливих зв'язків і включає показники концентрації уваги, урівноваженості нервових процесів, орієнтації у просторі, обсягу короткочасної пам'яті, переключення уваги. Тому його можна назвати фактором «формування основних професійно важливих якостей льотчика».

Другий фактор (Ф2-2гр.) пояснюе $32 \%$ загальної дисперсії і складаеться 3 трьох вагомих для льотної роботи психофізіологічних характеристик. Це проста зоромоторна реакція, орієнтація у замкнутому просторі, швидкість переробки інформації. Виходячи 3 того, що обговорюваний фактор має зазначені специфічні компоненти і є гібридом складових інших факторів, його можна назвати фактором «поведінки в екстремальних умовах». Структура обох факторів, що описують дисперсію психофізіологічних функцій у групі 2 , свідчить про наявність у стажованих льотчиків сформованого кореляційного каркасу професійно важливих якостей, що має розгалужену мережу взаємозв'язків психофізіологічних функцій. Наявність таких зв'язків психофізіологічних функцій дозволяе ім ефективно здійснювати свою професійну діяльність.

Дещо інші закономірності спостерігаються в групах практично здорових льотчиків. Тут у різних вікових групах виділено по три фактора, що пояснюють $71 \%$ - для вікової групи до 30 років і $55 \%$ - для вікової групи понад 30 років (рис. 2в, 2г). Така особ- 


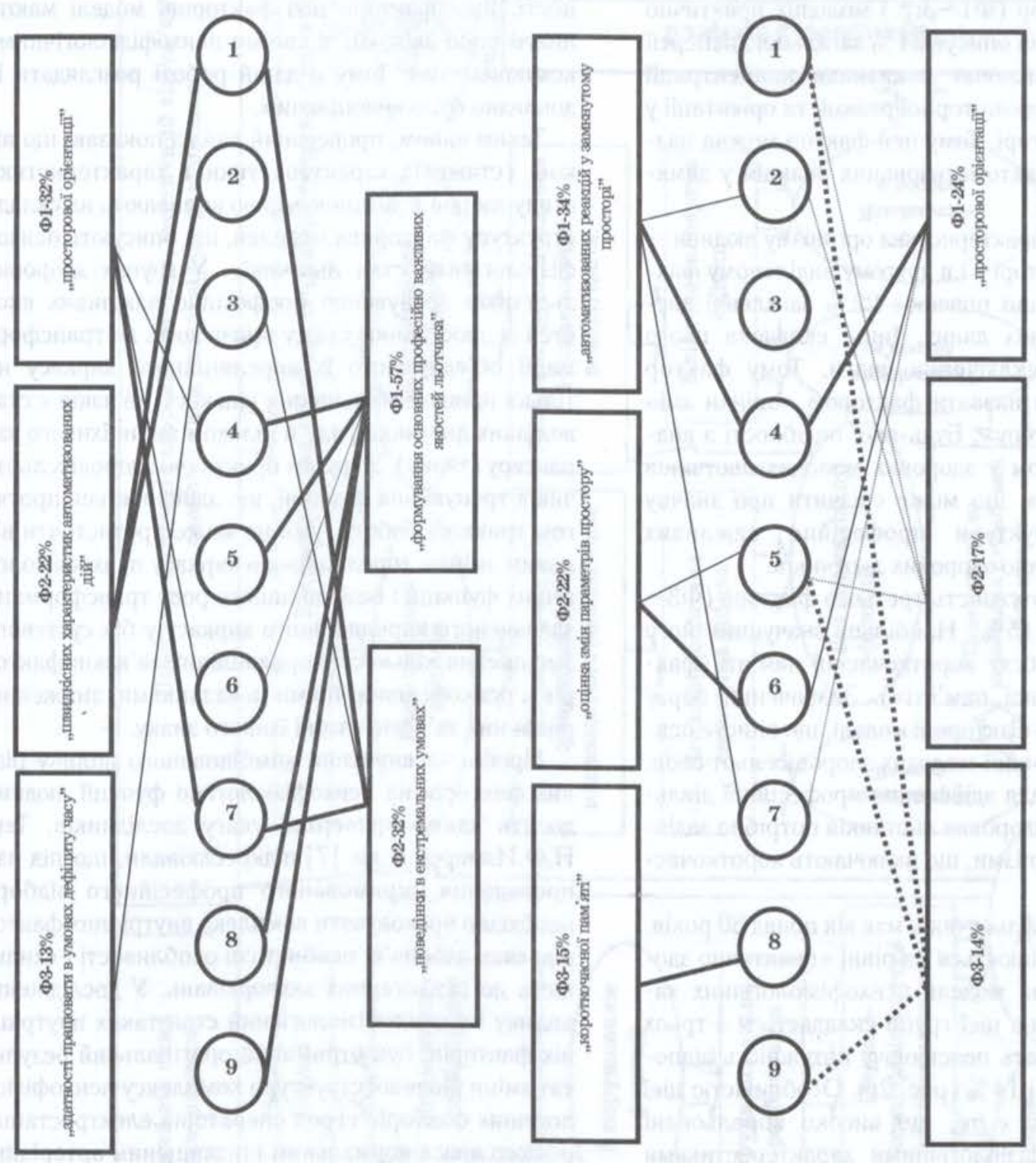

Сумарне факторне навантаження:

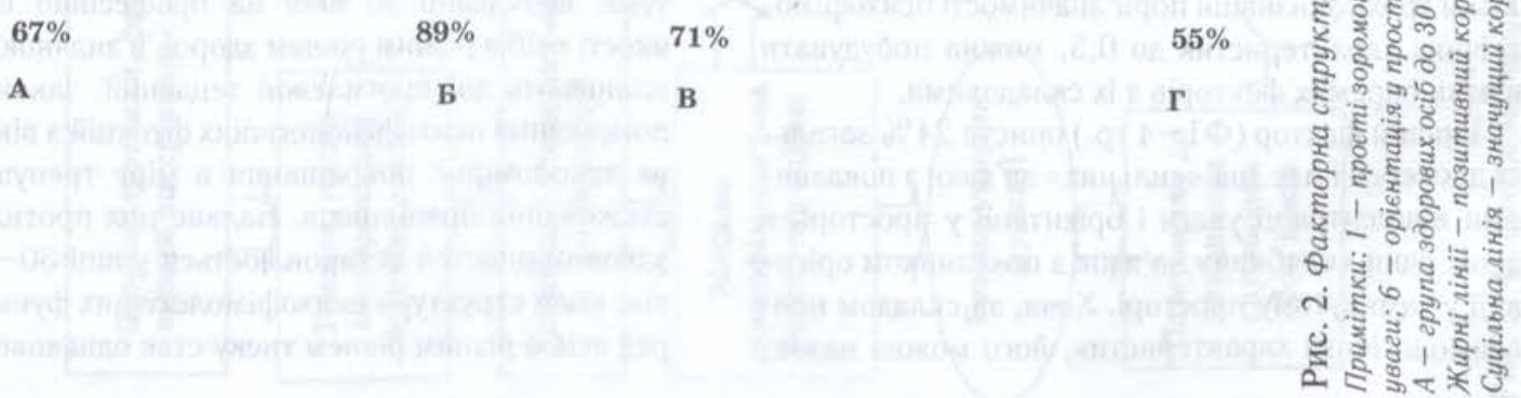


ливість побудови моделі, ймовірно, свідчить про те, що «організуюча» роль стажового тренування у групі практично здорових льотчиків уже не відіграє великої ролі, а вікові зміни значною мірою впливають на стан професійно важливих функцій.

Перший фактор (Ф1-3гр.) молодих практично здорових льотчиків описуе $34 \%$ загальної дисперсії (рис. 2в). Він включає показники концентрації уваги, складної зоромоторної реакції та орієнтації у замкнутому просторі. Тому цей фактор можна назвати фактором «автоматизованих реакцій у замкнутому просторі».

Але важлива характеристика організму людини орієнтація у просторі $є$ і в другому виділеному факторі (Ф2-3гр.), що пояснюе $22 \%$ загальної дисперсії аналізованих даних. Інша складова щього фактора - переключення уваги. Тому фактор Ф2-3 гр. можна назвати фактором «оцінки змін параметрів простору». Будь-якої подібності з аналогічним фактором у здорових молодих льотчиків не простежуеться, що може свідчити про значну перебудову структури професійно важливих якостей у практично здорових льотчиків.

Пояснююча потужність третього фактора (Ф33 rр.) становить $15 \%$. Найбільш значущим його компонентом є обсяг короткочасної пам'яті (фактор «короткочасної пам'яті»). Зазначений параметр не входив до факторної моделі, що описує психофізіологічні функції молодих здорових льотчиків. Це показуе, що для здійснення професійної діяльності практично здорових льотчиків потрібно задіяти додаткові механізми, що включають короткочасну пам'ять.

Наступна група льотчиків має вік понад 30 років, і їхне здоров'я оцінюеться на рівні «практично здоровий». Факторна модель психофізіологічних характеристик членів цієї групи складаеться з трьох факторів, що мають пояснюючу потужність відповідно $24 \%, 17 \%$ і $14 \%$ (рис. 2 г). Особливістю ціеї факторної моделі є те, що високо корельовані зв'язки 3 психофізіологічними характеристиками тут має тільки перший фактор, та й то частково. Тільки трохи знизивши поріг значимості психофізіологічних характеристик до 0,5 , можна побудувати зв'язки окремих факторів з іх складовими.

Перший фактор (Ф1-4 гр.) описує $24 \%$ загальної дисперсії і має два «сильних» зв'язки з показниками концентрації уваги і орієнтації у просторі, а також один «слабкий» зв'язок з показником орієнтації у замкнутому просторі. Хоча, за складом психофізіологічних характеристик, його можна назва- ти фактором «просторової оріентації», якість і кількість його зв'язків досить суттево відрізняється від аналогічних факторів $\Phi 1-1$ гр. і Ф1-3гр. Це свідчить про значні перебудови кореляційного каркасу, що сприяє забезпеченню професійної діяльності. Інші фактори ціеї факторної моделі мають нижчі рівні зв'язків зі своїми психофізіологічними компонентами. Тому в даній роботі розглядати їх докладно було недоцільним.

Таким чином, проведений аналіз показав, що вікові (стажеві) характеристики і характеристики стану здоров'я значною мірою впливають на склад і структуру факторних моделей, що описують психофізіологічний стан льотчиків. У групах здорових льотчиків тренування професійно важливих якостей зі зростанням стажу призводить до трансформації об'еднуючого іх кореляційного каркасу не тільки шляхом збільшення кількості зв'язків у стажованих льотчиків, але й шляхом зміни їнього характеру (знаку). У групах практично здорових льотчиків тренування функцій, що здійснюеться протягом тривалої роботи, уже не може протистояти віковим змінам кореляційного каркасу психофізіологічних функцій і веде до іншого роду трансформації зазначеного кореляційного каркасу у бік суттевого зменшення кількості кореляційних зв'язків факторів з психофізіологічними показниками, зниженню рівня цих зв'язків і зміні їнього знаку.

Проблема вивчення комбінованого впливу різних факторів на психофізіологічні функції люднни досить давно привертае увагу дослідників. Так, Н.Ф.Измеров и др. [7] підкреслювали, що під час проведення спрямованого професійного відбору необхідно враховувати комплекс внутрішніх факторів: стан здоров'я, особистісні особливості і схильність до психогенних захворювань. У дослідженні впливу на психофізіологічний стан таких внутріщніх факторів, був отриманий оригінальний результат зміни рівневої структури комплексу психофізіологічних факторів серед операторів електростанції різного віку з нормальним і підвищеним артеріальним тиском [8]. За його даними була висунута гіпотеза, відповідно до якої на професійно важливі якості осіб з різним рівнем здоров'я значною мірою впливають дві протилежні тенденції: закономірне погіршання психофізіологічних функцій з віком і їне закономірне покращання в міру тренування у стажованих працівників. Баланс цих протилежних закономірностей встановлюеться у віці 30-39 років, коли структура психофізіологічних функцій серед осіб з різним рівнем тиску стає однаковою. 


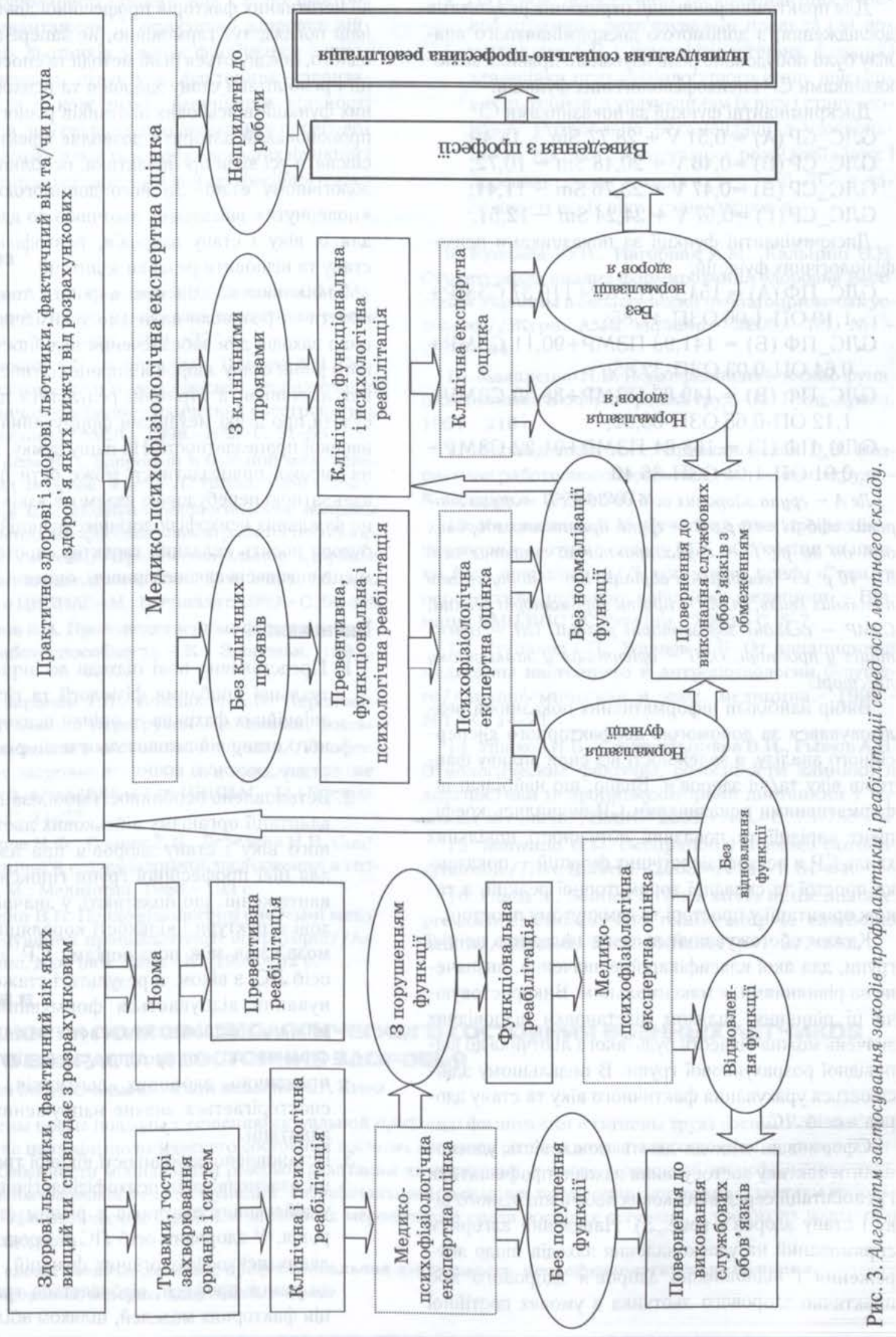


Для практичної реалізації отриманих результатів дослідження, з допомогою дискримінантного аналізу було побудовано розв'язувальні правила за показниками СР і психофізіологічних функцій.

Дискримінантні функції за показниками СР:

GЛC_CP $(\mathrm{A})=0,51 \mathrm{~V}+28,77 \mathrm{Sm}-14,49$;

GЛС_CР (Б) $=0,46 \mathrm{~V}+20,48 \mathrm{Sm}-10,72$;

GЛC_CP $($ В $)=0,47 \mathrm{~V}+23,76 \mathrm{Sm}-11,41$;

GЛC_СР $(\Gamma)=0,57 \mathrm{~V}+24,24 \mathrm{Sm}-12,51$.

Дискримінантні функції за показниками психофізіологічних функцій:

$$
\begin{aligned}
& \text { GЛС ПФ }(\mathrm{A})=154,29 \Pi 3 \mathrm{MP}+110,37 \mathrm{C} 3 \mathrm{MP}+ \\
& 1,19 \text { ОП- } 1,06 \text { ОЗП-41,85; } \\
& \text { GЛС_ПФ (Б) }=141,93 \text { ПЗМР+90,11 С3MP+ } \\
& \text { 0,64 ОП- } 0,03 \text { ОЗП-32,85; } \\
& \text { GЛС_ПФ }(\mathrm{B})=149,87 \text { П3МР+88,39 C3MP+ } \\
& 1,12 \text { ОП }-0,65 \text { ОЗП-33,82; } \\
& \text { GЛС_ПФ }(Г)=168,64 \text { П3МР+91,22 C3MP+ } \\
& \text { 0,91 ОП-1,01 ОЗП-36,40. }
\end{aligned}
$$

Де $A$ - група здорових осіб до 30 р.; $Б$ - група здорових осіб $31-40$ р.; B - група практично здорових осіб до 30 р.; $\Gamma$ - група практично здорових осіб 3I-40 p. V - коефіціент варіаціi, Sm - потужність повільних хвиль, ПСМР - прості зоромоторні реакції, СЗМР - складні зоромоторні реакціі, ОП - орієнтація у просторі, ОЗП - оріентація у замкнутому nросторі.

Вибір найбільш інформативних показників реалізовувався за допомогою двофакторного дисперсійного аналізу, в залежності від сили впливу факторів віку та/чи здоров'я. Видно, що найбільш інформативними показниками СР виявились коефіціент варіації та показник потужності повільних хвиль СР, а психофізіологічних функцій - показники простої та складної зоромоторної реакції, а також оріентації у просторі та замкнутому просторі.

Кожен обстежуваний льотчик належить до тієі групи, для якої класифікаційне значення, визначене за рівняннями, є максимальним. Використовуючи ці рівняння, шляхом підстановки відповідних значень можна віднести будь-якого льотчика до відповідної розрахункової групи. В подальшому здійснюеться урахування фактичного віку та стану здоров'я осіб ЛС.

Сформовані підходи дають можливість удосконалити тактику застосування заходів профілактики і реабілітації серед військових льотчиків різного віку і стану здоров'я (рис. 3). Наведений алгоритм спрямований на удосконалення заходів щодо збереження і відновлення здоров'я здорового або практично здорового льотчика в умовах постійної дії негативних факторів професійної діяльності. На наш погляд, тут гармонійно, не заперечуючи одне одного, поеднуються різні методи та способи корекції і реабілітації стану здоров'я та психофізіологічних функцій військових льотчиків різного віку. Запропонований алгоритм дозволяє ефективно здійснювати усі види профілактики, особливо на донозологічному етапі. За його допомогою можливо «повернути» військових льотчиків до адекватного, для ix віку i стану здоров'я, психофізіологічного стану та відновити резерви адаптаціі.

Таким чином, здійснені в роботі теоретичні та практичні розробки дали змогу визначити повний цикл заходів для забезпечення надійності та високого рівня стану здоров'я і працездатності військових льотчиків, а отримані результати дозволяють судити про деякі механізми формування серед них високої працездатності. На нашу думку, збереження високої працездатності може бути пов'язане 3 адекватною перебудовою взаємозв'язків професійно важливих психофізіологічних функцій. Ця перебудова носить складний характер, проте вона має місце визначені закономірності, описані вище.

\section{Висновки:}

1. Представлено нові підходи до вирішення актуальної проблеми фізіології та гігіени праці авіаційних фахівців - оцінки психофізіологічного стану військових льотчиків різного віку і стану здоров'я.

2. Встановлено особливості мобілізації резервів адаптації організму військових льотчиків різного віку і стану здоров'я при адекватному для ціеї професійної групи гіпоксичному навантаженні, що полягають у значній перебудові структури і кількості кореляційних взаемозв'язків між показниками СР. У здорових осіб ЛС, з віком, в результаті стажового тренування відбуваеться формування «оптимальної» відповіді його елементів для пристосування до конкретних умов діяльності. У практично здорових льотчиків, навпаки, спостерігається значне напруження резервів адаптаціі.

3. Встановлено особливості вікової трансформації взаємозв'язків психофізіологічних функцій у військових льотчиків з різним станом здоров'я. У здорових осіб ЛС в процесі становлення психофізіологічних функцій, відповідно до вимог професії, відбувається трансформація факторних моделей, шляхом збільшення їх 
структурованості, зміни рівня і знаку факторних навантажень. У практично здорових військових льотчиків з віком формуеться невпорядкованість структури факторних навантажень, а також різке зменшення кількості зв'язків, що свідчить про аномальну перебудову взаємозв'язків психофізіологічних функцій i дезорганізацію забезпечення професійної діяльності.

\section{Література}

1. Баевский Р.М., Кирилов О.И., Клецкин С.М. Математический анализ изменений сердечного ритма при стрессе.- М.: Наука, 1984.-221 с.

2. Белинский А.В., Чернов О.Э., Шакула А.В. Особенности диагностики и медищинской реабилитации при пограничных нервно-психических расстройствах у летного состава//ВМЖ.- 1998.- №2.- С. 51-56.

3. Бехтерева Н.П. Здоровый и больной мозг человека. 2-е изд. перераб. и доп.- Л.: Наука, 1988.-262 с.

4. Бодров В.А. Медико-психологические вопросы восстановления профессиональной работоспособности летного состава//Профессиональное здоровье летчиков и летное долголетие: Тем. науч. сб. в/ч 64688 и 7-го ЦВНИАГ.-М.: Воениздат, 1989.-С. 50-59.

5. Бузунов В.А. Производственные факторы и возрастная работоспособность.- К.: Здоровья, 1991.$160 \mathrm{c}$.

6. Вартбаронов Р.Л., Кондаков А.В. Переносимость длительных перегрузок летчиками, имеющими отклонения в состоянии здоровья//Профессиональное здоровье летчиков и летное долголетие: Тем. науч. сб. в/ч 64688 и 7-го ЦВНИАГ--М.: Воениздат, 1989.- С. 21-23.

7. Измеров Н.Ф., Гурвич Е.Б., Лебедева Н.В. Соціально-гігієнічні й епідеміологічні дослідження в ririені праці.- М.: Медицина, 1985.- 192 с.

8. Кальніш В.В. Психофізіологічні системні механізми формування працездатності операторів//Автореф. ... дис. д-ра біол. наук.-К., 1996.- 32 с.
4. На основі побудованих дискримінантних моделей отримано розв'язувальні правила (за показниками СР і психофізіологічних функцій) для оцінки психофізіологічного стану військових льотчиків, з урахуванням іх віку і стану здоров'я. Розроблено рекомендації з удосконалення тактики застосування реабілітаційних і профілактичних заходів серед осіб ЛС, в залежності від іх віку і стану здоров'я.

9. Кундиев Ю.И., Нагорная А.М., Кальниш В.В. Структурный анализ формирования здоровья населения Украины в әкологически неблаготриятных условиях//Журн. АМН України.- 2003.- Т.9, №1.C. 93-104.

10. Макаренко Н.В. Психофизиологические функции человека и операторский труд.- К.: Наук. думка. 1991.-216 c.

11. Навакатикян А.О., Крыжановская В.В. Возрастная работоспособность лищ умственного труда.К.: Здоров'я, 1979,- 207 с.

12. Наконечний В.М. Сучасний стан професійного здоров'я льотного складу ВПС ЗС України та шляхи його покращення//Наук.-практ. конф. "Стан та перспективи розвитку авіаційної медицини".- Вінниця: ВМц ВПС ЗС України.- 2003.- С. 5-7.

13. Ступаков Г.П., Ушаков И.Б. От авиационной медищины настоящего к антропоэкологии будущего//Авиакосмическая и экол. медицина.- 1998.№1,-C. 14-21.

14. Ушаков И.Б., Синопальников В.И., Рыжов А.Н. Этиологические факторы, особенности клиники и диагностики нейроциркуляторной дистониии у военных летчиков//ВМЖ.-2001.- №8.- С. 73-75.

15. Manzano G.G. Occupational disease. Burnout syndrome//Rev. Enform.-2003.- №11.-P. 51-54.

16. Pflanz S., Sonnek S. Work stress in the military: prevalence, causes, and relationship to emotional health//Mil. Med.-2002.- №167(11).-P. 877-882.

\section{Кравчук В.в. \\ ОСОБЕННОСТИ ПСИХОФИЗИОАОГИЧЕСКОГО СОСТОЯНИЯ ВОЕННЫХ АЕТЧИКОВ РАВНОГО ВОВРАСТА И СОСТОЯНИЯ ЗАОРОВЬЯ}

\section{Украинская военно-медишинская акацемия, г. Киев}

Представлены новые подходы к решению актуальной проблемы физиологии и гигиены труда военных спещиалистов - оценке психофизиологического состояния военных летчиков разного возраста и состояния здоровья. Установлены особенности мобилизации резервов адаптации их организма, а также возрастной трансформации взаимосвязей психофизиологических функций. Разработаны рекомендации по усовершенствованию тактики использования профилактических и реабилитационных мероприятий среди военных летчиков, с учетом их возраста и состояния здоровья.

Ключевые слова: военные летчики, профессиональная деятельность, психофизиологические функции, состояние здоровья, резервы адаптации, возраст 


\section{Kravchuk V.V.}

\section{PECULIARITIES OF MILTARY PILOTS' PSYCHOPHYSIOLOGICAL CHARACTERISTICS IN VARIOUS AGES AND THEIR HEALTH STATUS}

Ukrainian Military Medical Academy, Kyiv

The new approaches are presented to solving an actual problem of physiology and occupational health of military specialists assessment of psychophysiological state of military pilots of various age and state of their health. The peculiarities have been established of the mobilization of adaptation body reserves and the age transformation in interrelations of psychophysiological functions. The recommendations have been developed for improvement of approaches to the use of preventive and rehabilitation measures for military pilots with due account of their age and state of health.

Key words: military pilots, occupational activity, psychophysiological functions, state of health, adaptation reserves, age

Поступила: 06.05.2006

Контактное лицо: Кравчук Віктор Володимирович, кандидат медичних наук, доцент кафедри військової токсикології, радіології та медичного захисту Української військово-медичної академії, 04111, Київ, вул. Салютна 1-а, №4, к. 104, тел. 8-050-6562665 